\section{INTERNATIONAL ACTIVITIES IN SCIENCE*}

\author{
BY SIR HENRY DALE, O.M., G.B.E., P.R.S.
}

$\mathrm{W}$ ITH the outcome of the War ever more certain, there can be no relaxation yet of the demand on what our scientific effort can contribute to the hastening of its end. It is none the less our duty to begin to look further ahead and to prepare for the part which science must play in the world which will follow. The needs of alliance in war have evoked, especially between the two great branches of the English-speaking nations, a closer interchange and collaboration in science, between men of different national traditions and loyalties, than has ever before been a matter of organized policy. It is not too early to begin to consider to what degree, and in what form, such a collaborative effort should be continued into the conditions of peace, and extended to scientific men of international goodwill throughout the world. Even in the twenty years of uneasy armistice which ended in 1939, a measure of co-operation among the world's scientific men was achieved.

Our traditions go back to days when the fellows of the Royal Society belonged to a community embracing all Europe in its enthusiasm for the new experimental philosophy, and the Society will have a particular duty to be among the leaders in the resumption of international activities in science, and to use all its influence to establish these on an ever wider and firmer basis. The Society has a standing committee on intermational relations in science, with its foreign secretary appropriately as chairman, to prepare for what action the Society can usefully undertake or promote, as the opportunity presents itself. Meanwhile, we may observe other signs that the spirit of international friendship and recognition in science is beginning to move again, even while the chaos of war is still with us. Among such signs, we may note that one of the committees which, since their foundation in Stockholm, have awarded the Nobel Prizes with unchallenged impartiality among the scientific discoverers of all nations, has resumed awards this year. The Royal Society has welcomed the return to London of a group of distinguished French leaders in science from the United States of America, whither they had escaped from the hostile occupation of their country. We have been able to share their rejoicing at the liberation of France, and to welcome here others who had remained there, often in hiding and always in peril, as leaders in the steadfast resistance opposed by all but a negligible minority of the French men of science to the enemy's demands for their collaboration. Even to-day we are able to welcome another distinguished French colleague, just arrived from Paris - Prof. Emil Borel. We are glad to think that new and lasting bonds of comradeship in science have been created for us with those from other allied countries occupied by the enemy who have been our country's war-time guests, and through them with all the men of science in the countries which they represent. A happy chance brings also to our meeting to-day four men of science from the U.S.S.R. Very near to the heart of every British man of science is the desire for a growing intimacy of confidence and collaboration with our colleagues of that

* From the address at the anniversary meeting on November 30. great partner-nation in the war for the world's freedom.

The Royal Society had recently the opportunity of showing its interest in the revival of international scientific co-operation in another special connexion. During October 16-19, a small international conference met in the Society's rooms, under the auspices of the Health Organisation of the League of Nations, to discuss the creation of an international standard of reference for penicillin and the definition, in terms of this, of a unit of activity.

Though the League has failed tragically of its central purpose, it has achievements of value to its credit, and science has an interest in ensuring the permanence of some of these. I have myself had the privilege of taking part in the activities of an international commission under the Health Organisation of the League, which succeeded, in the years between the Wars, in obtaining world-wide acceptance of standards and units of activity for a whole range of modern remedies-antitoxins, hormones, vitamins and certain drugs-the strength of which could only be determined by direct biological measurements of the specific activity, in comparison with that of a fixed standard preparation in each case. Insulin was an early instance of a new remedy requiring such intervention; its general use for the treatment of diabetes could not have attained the present level of safety and effectiveness, unless a world-wide uniformity on these lines had replaced the chaos of widely different units in different countries, which was threatened in 1923. Now research has produced another new remedy, penicillin, the success of which, in the treatment of a range of dangerous infections, has also had such a dramatic quality that its reputation has spread rapidly beyond our scientific community and caught the interest even of a war-distracted world. Here, indeed, was a discovery which could rank as a major contribution of science to the mitigation of the suffering which war inflicts, and, at the same time and no less, as a gift of healing to mankind at peace. The needs of war had given a stimulus to the researches which proved penicillin's remedial value, but its rapid production on an adequate scale had to face greater difficulties in Great Britain, where material and human resources had been more completely absorbed by earlier requisitions than in the United States. So the present position was reached, in which, as we are proud to recognize, the existence of penicillin and then, after a decade, the methods by which it could be separated in sufficient purity to demonstrate its brilliant possibilities as a remedy, were discoveries made here in England, while, in the further researches and technical developments needed for its large-scale production, our American colleagues have played a major part.

Thus early in its history, therefore, penicillin and its applications had become a matter of international concern ; and, though war had restricted the work in this field almost entirely to scientific workers of the English-speaking peoples, and had brought them into an unusual intimacy of co-operation, progress had been so rapid and action so urgent that there was a real danger of a divergence of meaning in the terms used to express its activity and define its dosage, even among the few countries already using it. Prompt action was required to avert this by accepting a common standard of reference ; and, when the proposal of a conference for this purpose was made from Great Britain to the League of Nations Health Organisation, we were grateful to our colleagues from the United 
States, as well as from Canada and Australia, for the generous promptitude with which they agreed to make the journey to England, so as to meet with us here in London. After all arrangements for the holding of the conference here had been completed, the liberation of Paris opened a new possibility; Dr. Tréfouel, now director of the Pasteur Institute in Paris, was able at the last moment to accept an invitation to join us, and thus to give our deliberations, and our eventual agreement, a wider intermational basis.

To illustrate how rapidly a divergence may arise under present conditions, I may just mention the fact that several different penicillins have now been recognized, produced by variations in the metabolism of the growth, possibly due to mutations of the mould itself, possibly to changes in the nutritive conditions offered to it by the medium or the cultural method employed. Three such varieties of penicillin have already been isolated in pure condition, and distinguished by certain chemical characters ; but, while British workers had come to refer to these as penicillin 1, 2 and 3, their colleagues in America spoke of penicillin $\mathrm{F}, \mathrm{G}$, and $\mathrm{X}$; and it was not until they met around the table at the Royal Society a few weeks ago, but then in less than ten minutes, that they became quite certain of the identity of 1 with $F$, of 2 with $\mathrm{G}$, and of 3 with $\mathrm{X}$. All these penicillins have the specific remedial action in high, though not quite identical degrees, and there are probably differences, still to be explored, in their proportional efficiencies against different infective organisms. When once their identities were thus put beyond doubt, however, the small conference had no hesitation in deciding, for the present, to use as the common basis of reference a sample of the penicillin which is predominant in most preparations now available, and most easily obtained as a pure salt in adequate quantities. The unit could then be defined as the activity of a precise, though very small weight- $-0.6 \mu \mathrm{gm}$. - of a particular sample of the perfectly dried, crystalline sodium salt of penicillin 2, or $G$; and the unit thus chosen for definite fixation, and for international recognition henceforward, was, by a unanimous choice, so defined as to be as closely equivalent as possible to the unit first propounded by Sir Howard Florey's team of collaborators, and widely known as the 'Oxford' unit.

The international standard for penicillin is thus added to an already numerous series, of which the custody, on behalf of the League of Nations Health Organisation, has been shared by the National Institute for Medical Research with the State Serum Institute of Denmark, at Copenhagen ; and all these standards, we may hope, will be available for transfer to whatever international authority may be established in succession to the League, as a tangible and material result of genuinely intermational collaboration, which the League has been able to initiate and maintain among men of science, to the permanent advantage of the world.

Though penicillin has rightly made a special appeal to the imagination and sympathetic interest of a wide public, it is, of course, only one out of a varied range of inventions and discoveries, hastened by the stimulus of war's demands and produced, in many cases, behind the veil of its secrecy ; but ready, when peace returns, to take their proper place as new gifts to the welfare and the civilized progress of mankind. From what has already been made generally known, it is clear that we may look forward to revolutionary advances in the means of communication and in the speed and safety of travel across the world and in methods of controlling insect pests and the diseases which insects convey. These are but a few examples of the gains which we and the world may hope to set against the tragic loss and sacrifice of the years of war.

There were probably few who even suspected in 1939 that science, in countries then so dangerously unready, would find itself, before the War ended, in its present position of central importance. None of us, I think, would claim more for science even now, than to have played in this War a part of growing predominance in the provision for the fighting men of the material means of warfare, without which their heroism and sacrifice could not have prevailed. Even that duty, loyally accepted, is one from which the scientific community of the free nations must long for the release which victory will bring. But, while the operations of war have come to depend on science to a degree beyond all earlier experience, it cannot be doubted that little more than a beginning has yet been made in exploiting the possibilities of destruction, which science could progressively offer, if the world should continue thus to misuse it, and if science were still on offer for such ends. Allow me to quote a passage from a letter which the Prime Minister, whom we are proud to number among the fellows of the Royal Society, wrote a year ago to Prof. A. V. Hill, in sending his greetings to Indian men of science.

"It is the great tragedy of our time," wrote Mr. Churchill, "that the fruits of science should by a monstrous perversion have been turned on so vast a scale to evil ends. But that is no fault of science. Science has given to this generation the means of unlimited disaster or of unlimited progress. When this War is won we shall have averted disaster. There will remain the greater task of directing knowledge lastingly towards the purposes of peace and human good." Noble words indeed, and a profession of faith which will find an immediate echo in the hope and the desire of every true man of science. "When this War is won we shall have averted disaster" - surely that is a confidence which every one of us will long to share. It must be clear, however, that Mr. Churchill's reference was to the present threat of disaster, from which the prospect of our escape is even more fully assured to-day than when he wrote, a year ago. We may be certain that nobody sees more clearly than he that the threat of final disaster to all man's hopes and achievements will not be for ever averted, if the possibility of the "monstrous perversion" of science is allowed to remain and to continue its evil growth. Even in the past year our enemies have thrown a new and vivid light on future possibilities, by the new weapons which science has enabled them to put on trial for our destruction. Though a people's unflinch. ing courage and an answering effort of science and organization, together with the progress of the Allied Armies over the launching areas, have given us confidence that flying bombs and the like will not affect the issue of this War, the warning which they give, as to what the future might hold, is not the less clear. The writing on the wall must be plain for all to read. If, when the memories of the present War begin to fade, the world should allow science again to be exploited by a nation grasping at predominance by conquest, science will no longer be invoked only as an aid to what valour can achieve by land, sea or air, but as an agent, in itself, of blind annihilation at an ever-lengthening range. 
When we men of science regain that freedom for the ultimate preservation of which we have loyally accepted, through these tragic years, the bonds of secrecy and submission to authority, we cannot put aside with these our proper share in the new responsibility for the future of mankind, which the experiences of this War have laid upon the men of goodwill in all nations. It is true, indeed, that neither the present abuse of science, nor any possibility of final disaster to civilization which might come of a future perversion of its powers, can be charged as a fault to science itself; no more, indeed, than we could properly charge to religion, as such, the wars which once devastated much of Europe in its name. But we men of science cannot escape from our growing share in the responsibility, in "the greater task", as Mr. Churchill has written, "of directing knowledge lastingly towards the purposes of peace and human good". No man of science has the right to prescribe for another his interpretation in detail of that duty; but there is one aim which may unite us, perhaps for the most effective action within our common grasp, and one which is worthy of all our common influence and effort. Let me quote again from Mr. Churchill's letter: "in this task", he writes, "the scientists of the world, united by the bond of a single purpose which overrides all bounds of race and language, can play a leading and inspiring part".

\section{ROYAL SOCIETY MEDAL AWARDS, 1944*}

\section{Copley. Medal}

\section{$\mathrm{T}$} HE Copley Medal is awarded to Sir Geoffrey Ingram Taylor, Yarrow research professor of the Royal Society, in recognition of his contributions to knowledge of aerodynamics, of hydrodynamics and of the structure of metals, which have had a profound influence on the advance of physical science and of its practical applications.

Taylor is probably the most accomplished living exponent of the application of the methods of classical dynamics to problems of fluid motion. To great mathematical powers he adds high skill as an experimenter. His theoretical work is particularly noteworthy for its approach to reality. In place of the ideal conceptions presented by perfect incompressible fluids moving in stream-line motions and perfectly elastic solids, with which his great forerunners at Cambridge dealt, Taylor has studied turbulent motion, viscous and compressible fluids, and plastic movements of metals, obtaining results of great importance for the understanding of a wide range of phenomena.

Taylor's early work was concerned with eddy motion in the atmosphere, and opened up new fields of meteorological investigation. It threw light on the variation of wind with height and on the transference of heat and water vapour in the atmosphere, with a consequent bearing on the formation of fog. He also carried out work on the tides. Later he developed the theory of general turbulence, to which statistical methods can be applied which are somewhat reminiscent of the kinetic theory of gases.

Among Taylor's extensive researches on precise

* Remarks made by Sir Henry Dale in presenting the Royal Society Medals for 1944 . hydrodynamical problems, that on the motion of a viscous fluid between two coaxial cylinders, rotating with any speed in the same or in opposite directions, may be particularly mentioned, since it offers the only case so far of the complete solution of a problem of motional instability in the viscous liquid. In dealing with the elastic deformation of metals, Taylor has shown how the slip planes can be determined in certain cases by purely geometrical methods, and has offered a formal theory of the process of workhardening in single crystals.

Taylor has also applied his great mathematical powers to a variety of practical questions. During the War of 1914-18 he did work of great distinction on aerodynamical problems for the Advisory Committee on Aeronautics, and during the present War he has been extensively concerned with complicated problems concerning the propagation of explosive processes. Taylor's work may be said to be in the line of a great British tradition, which, in the past generation, was represented by investigators like W. J. M. Rankine, Osborne Reynolds and Rayleigh. Like these he has the mathematical equipment, the originality and the insight required for the fundamental solution of problems presented by practical experience in the laboratory, in the workshop, and in the wider world. Taylor has carried his quest for experience and for scientific problems on to the sea and into the air. His work during this War has been of the greatest value to the nation and its allies, and his fundamental discoveries are extending the boundaries of knowledge for all mankind.

\section{Rumford Medal}

The Rumford Medal is awarded to Dr. Harry Ralph Ricardo, consulting engineer, in recognition of his important researches on the internal combustion engine.

There is a special fitness at the present time in the award of this Medal to one who, during the last twenty years, has been the leading spirit in the development of the high-speed internal combustion engine. Ricardo's researches were begun under Bertram Hopkinson in 1905 and continued, after he left Cambridge, as a consulting engineer in his grandfather's firm. Investigating the effect of turbulence on the speed of combustion, he was led to appreciate the importance of 'knocking', to determine its cause and to show that the tendeney to ' $k$ nock' is dependent on the nature of the fuel. Taking charge of a special design department for his firm, he produced a fourcycle, supercharged aero-engine, long in advance of accepted practice. In 1916 he was invited to plan a special engine for the secret fighting machine which was to become known as the tank, and his unorthodox and daring design was an outstanding success.

Forming a private company to maintain a labora. tory for research on the internal combustion engine, Ricardo further investigated the relation of the phenomenon of 'knocking' to the maximum compres. sion-ratio of the engine and to the character of the fuel, matching the latter by adding toluene in variable proportion to heptane, and thus paving the way for the modern octane-rating.

It is not possible here to make more than general reference to the far-reaching influence of Ricardo's investigations and his steady advocacy on the designs of slide-valve engines, of sleeve-valve aero-engines, of high-speed Diesel engines, and on other important developments in engine design. In all directions there is evidence of his special genius and flair for design, 